\title{
Study on the Influential Factors of Employment for the Economic Management College Students in Agricultural University under Financial Crisis Background
}

\author{
Hong Pan \& Renhui He \\ School of Economics and Management, Sichuan Agricultural University \\ Ya'an 625014, Sichuan, China \\ E-mail: panhong780@126.com
}

\begin{abstract}
At present, there are some typical problems in economic management college agricultural university undergraduates' profession decision-making, such as taking up an occupation passively, not feeling satisfied with current work and so on. Aiming at these phenomena and based on the background of the financial crisis, in the paper, the author analyzed the cause from the angle of the graduates and carried through the SWOT analysis of employment competition. The results indicate that agricultural universities should strengthen the development of person with ability that could accord with the demand of social economic, strengthen education linked to the theory and practice of education, strengthen its employment training capacity and improving the competitiveness of employment.
\end{abstract}

Keywords: Financial crisis, Economic management undergraduates, College students, Employment competition

\section{Research background and significance}

After the financial crisis is in the United States of the spreading subprime mortgage crisis, the global economy hit a bottom, and picks up until the next round of growth cycle before a time interval, it may be two years or three years, or eight years and ten years and even more. Following the European and American economy showed signs of stable improvement, the global economy from the edge of collapse into the "after the financial crisis times".

Because of the effect of financial crisis existing the hysteretic nature, changes in China's economic situation, the impact on employment is not only in the current period, and often lags some time to fully emerge. It is an important part of the macro control for every country in employment and employment rate is also an important indicator in a country's economic level. A number of labors =employed +unemployed, so employment situation is often used to reflect the overall employment situation. From the long-term economic situation, the unemployment rate will return to nature unemployment rate, but which really leads substantial impact on economic is short-term fluctuations. Phillips curve will be linked to inflation and unemployment that is out of the linear relationship between them. "There is temporary measure circumstance between inflation and unemployment, but there is no permanent judge of the balance. A temporary measure doesn't judge from inflation itself but unexpected inflation will reduce unemployment but high inflation can't."

Thus, the high inflation not only failed to reduce unemployment, but also made unemployment rising. According to related statistical prediction, from 280 million college graduates in 2004 to 611 million in 2009, an increase of 5 years is up to $118.2 \%$. By 2011, the number of university graduates will reach a peak of about 758 million, for a long time in China's future, the employment pressure on university graduates will not be weakened (1). Employment competitiveness refers to the concept of university graduates, job orientation, career planning, employment technology, and other capacity of subjective and objective factors. As a special group, university undergraduates will face many challenges and press, one of what is more and more graduates need employment and other side is a large number of unemployment army and reducing of jobs, which making the room of graduates' employment smaller and smaller, making the employment more difficult, the employment situation is very grim. For the more, the agriculture college graduates faced more challenges and more pressure in the employment, especially in economics and management graduates of agricultural university in west china.

With the spread of financial crisis and the serious employment situation, the most of undergraduates choose to hunt job initiatively. But with unoptimistic expectations of the worldwide economic downturn, the phenomena that passive employment and "the net group" begin to appear. 
Therefore, in this paper, study is on the employment behavior of these students who are graduated from Economics and Management College of Agricultural University and we hope it can help to resolve how to cultivate and improve the competitiveness of graduates to achieve employment under the severe pressure to find a satisfactory job.

\section{The overall employment situation}

\subsection{Basic employment situation}

This paper is with the economics and management graduates of grade 2010 adding up to 638 in Sichuan Agricultural University for investigation object. 630 self-designed questionnaires were hand put $(98.75 \%$ of the total number) and 532 questionnaires responded (response rate was $84.5 \%$ ).

\subsection{The level of job satisfaction}

The investigation showed that the students are given priority in employment opportunities and income, employment increasingly materialistic and utilitarian.

2010 graduates do not fell very satisfaction for the existing works overall, only $12 \%$ satisfied, $40 \%$ generally satisfied, $17 \%$ dissatisfied and 33\% not clear. Last two answers together accounted for half of the total number of graduates. This is a direct reflection of the existing work in the work environment, income, career development, social status, value realization and so the expecting situation from the graduates themselves being far away.

\subsection{Employment orientation}

The investigation showed that there are $1 / 3$ graduates who has already begun work hoping to stay in the original work unit, But more students are to leave their current work unit to find a new job, start a business, study, and do other ways to change the current situation.

This also shows that the graduates after entered the society, with social experience and competitive pressures increase, consider more practical issues and start from many aspects of their life planning.

\section{Cause analysis}

Although the global economy has begun to thaw, the employment situation is still prominent, especially for the undergraduates.

Attribution, from the literal meaning, is attributed the causes of conduct. Attribution style can be said to come from a cognitive psychology style of perception, it connects personal characteristics of personality and one's attribution cognitive process, which is a unique way of attribution. Attribution style on the impact is particularly important, because it is a form of long-term stability and relative tendency or characterized, and its impact is constant and regular. Attribution style shows different characters on different students.

\subsection{The lack of clear career planning}

The investigation showed that $22 \%$ students have a clear career planning, $63 \%$ have a more obscure career planning, while $15 \%$ have no career planning. As the saying goes, "forewarned is forearmed, while not pre-waste", good career planning for the university graduates has a positive role in guiding their four years life. But the case from the survey, college students' awareness of career planning is relatively weak, and they lack motivation to learn when they have entered college, have no clear career goals, and are passive personal development. Because of lacking of long-term career development planning, many college students on campus did not follow the career objectives to create the overall quality of individuals (2).

In the survey, $1 / 5$ students have a clear proportion, and other $63 \%$ students have no or not clear career planning. Career planning being not clearly lead to that it is hard for the students to have a more systematic thinking about the future at the university four years and don't know what job is suitable for them or only have an indistinct understanding to future job. It induce that the students begin to think about their profession in a hurry when they approaches graduation. So it is easy for the graduates to resign or change job in a short time.

\subsection{Lack of effective self-knowledge}

Through investigation and analysis showed that the majority of students not yet have a clear understanding of their own work under the premise when they begin to do such as job hopping, taking the postgraduate entrance exam, starting their own businesses and other new ideas, showing frequent changes and unstable in their work. This directly led to students not yet clear whether the existing work for urgent change in the work under the premise of even the industry, increased employment opportunities for graduates to choose the cost, but also led to the employment situation of graduates for the future production is not optimistic estimate.

To some extent, caused by acts of such employment because graduates consider when job satisfaction is that they 
focus more of existing wages, benefits and other practical factors units, lack of business development prospects and personal development opportunities and other long-term considerations, once the heart of Reality and is expected to produce graduates contrast to produce thoughts of quitting, it is difficult to achieve anything in the workplace.

\subsection{The lack of appropriate vocational skills}

Survey shows that the career competency which the graduates are willing to train and open up and development are professional skills (41\%) and ability level (22\%). It is said that, Indicate the actual work process, most graduates are hard to adapt the technical requirements of their work. This is in relation to economics and management training models. Economic management students in particular, the content of undergraduate study more general, not very high technological content, the main focus on theoretical knowledge of the cultures, the whole is soft technology (even financial management, international trade is only half of the professional skills), it is difficulties involved in the process of business management aspects of practical application, this way the process of competition in a weak position. In the actual course of their work, business management graduates feel that working in a single, low-tech, mainly engaged in writing and marketing aspects of business, increased sense of space is relatively small, difficult to dry out the concrete results, in the post promotion, wage incentives, subsidies and so the point is helpless.

\subsection{Single job access to employment information and high cost}

In the employment process, students generally felt that too little employment information is a key reason leading to the difficult employment (accounting for $41.35 \%$ of those surveyed), employment information led to some students less passive acceptance to the school recruited. Thus, $51.3 \%$ of the graduates felt a strong need timely access to employment information

Survey, administered by Agriculture and Forestry University class of college students, students from rural families accounted for $65 \%$ of total number of students, students from poor families accounted for $70 \%$ of the total number of students. Also, because the school is located in Ya'an, lagging economy, especially the financial sector, providing work units less developed areas in Chengdu, the high cost of job search costs, also contributed to the reasons for the unsatisfactory employment

\subsubsection{Lack of social experience}

School training mode is mainly reflected in the theoretical direction of education, lack of social education training for students, or students of social education is not active, a direct result of students into the community after graduation only book teaching but lack social experience, difficult to quickly gain a firm foothold in the community, increased employment costs

\subsubsection{Employment difficult to achieve professional counterparts}

Some agricultural and forestry colleges administered by the Curriculum in Curriculum and society, especially not meet the actual needs of the employer, a direct result of a "training school personnel and units should not, in need of a school does not train people," difficult to achieve professional counterparts, the graduates embarrassment of employment, increase the students have learned in school during the professional is not interested in education resulted in increased costs

\subsubsection{Internship opportunities too few, leading to a lack of self-awareness of students}

Survey, $41 \%$ of the graduates that the training should focus on skills that the successful achievement of the employment impact of the role of small, while the ability of individuals to a job that are particularly conspicuous. Graduates in their quality, ability and knowledge structure of the sort of job quality, practical ability came in the first place. As the Economics and Management is not a dominant subject in the agricultural and forestry colleges, the funding shortage, it is difficult to open up practice effective platform for the students at school to carry out the lack of opportunities to practice their counterparts in corporate internships, the students at school the knowledge is difficult to apply in practice difficult to understand the process of self-employment shortage, so that students can not learn in school continuously improved during the period

\section{Agricultural and Forestry University economics and management graduates competitive SWOT analysis}

SWOT analysis (self-diagnosis) is a more objective and accurate way to analyze and study the reality of a unit method. Using this method can find out to their advantage, it is worth promoting factors, as well as to their disadvantage, and how to avoid things, find problems, identify solutions, and a clear direction for future development. SWOT approach to economics and management in Sichuan Agricultural University to analyze the competitiveness of graduate employment, the following conclusions 
$<$ Table $2>$

\section{Related Countermeasures}

\subsection{Career Planning courses start from the new}

For the students, learning atmosphere, sense of team and even ways of exchanges with others are primarily in the freshman year into being, only to establish their own future life goals and career expectations to four years of university life and strive for the ideal. In College life, and career planning, design, design a platform to inspire the students enthusiasm, good career planning efforts, grouped into file, of the students in the ideological understanding, learning attitude, professional ideals such as understanding the situation, guide the students to integrate the actual periodic continuously improve the situation, and to develop detailed implementation steps, and continuously to achieve the employment goals. What the universities and teachers need to do is through provide college students with a good guide to make a early career plan and provide a lot of employment information and related training to them, the students can stand out in the case and play a good role in the first.

\subsection{Strengthen the practice and guide the graduates of the grass-roots employment}

College graduates produced "educational products", in the teaching activities, universities should strengthen the practice design, create opportunities for students and employer's access to students involved in the job market early, early preparation for employment. Meanwhile, construction of specialized laboratories should be strengthened to enable students to pass the practical operation of this specialized field of knowledge relating to deepen understanding and to develop their practical ability, to work for the next job to prepare in advance(3).

Next, for the lack of hard technologies administered by the actual situation of graduates, universities should encourage students to broaden their knowledge, research, etc. as a means to improve the overall quality of self, to overcome the inferiority complex of agricultural colleges with students, dare to compete, dare to compete, good competition, and improve their employability and competitiveness.

Last, guiding students to correctly understand the grassroots and understand the grassroots. It is necessary to correctly understand the grassroots, which can establish a mentality of success in their career, from the heart to overcome the prejudice against the grassroots.

\subsection{Segmented professional education and promoting employment ability}

Conducting professional education to enable students to clearly understand, agricultural and forestry colleges economic management is to study the professional features "three rural" aspects of the issue in the "three rural" areas of social need, what I can do, what I'm lack of. Targeted at vocational junior elementary education, middle grades professional quality development, high grades to improve their employment skills training to improve their employability.

The most crucial question of employ ability is how the college students transmit all kinds of capital and the information to the market, allowing the market to understand their own values, how to express the professional capacity they possess to the market by language or test. Getting jobs is the basic prerequisite for career development in the future. In professional capacity, the key is the attitude-type assets of representation for professional dedication and ethics. The foundation is knowledge skills-type assets of representation for the ability of solving problems. In market capacity, to look for better career development, university students must learn the whole labor market, especially the labor market's demand and supply information and structural information, understand the specific demands of the position and the level of employment, also need to develop demonstrate ability, so university students can employ successfully with high quality.

\subsection{Excavate the people network and expand employment opportunities}

Even in the perfect labor market system of developed countries, it plays an important role to make use of the capital based on the people of social network for the college students to find jobs. For example, more than half of MBA graduates of the Harvard are using the old man's relationship to find work.

In our country's cultural background, the use of social connections network has become a typical feature of action in college students' employment. Especially in the employment market situation, the use of the networking resources for the job seems especially important for success. At the social connections network the student's use, the number of selecting parents is the most. If the importance of developing and maintaining and excavating alumnus resources can be seen, it will play a more effective role on employment.

\section{Conclusions}

Professional and educational model to set unreasonable demands from the social problems leading to one of the reasons graduates, university personnel training pattern and socio-economic development needs of docking is not 
enough university education and practical skills needed to butt enough, university students ability of employment during the school enough to learn the real line with the actual work required something less practical (4). Therefore, curriculum and practical arrangements for conducting the process, should give full consideration to the Economic Management of the special circumstances, increase the theory and practice of education, combined with education efforts to continuously improve the competitiveness of student employment, improve the quality of employment

\section{References}

Cai zhifang. (2010). Graduates Employment Analysis and Countermeasure. Ideological \& Education, (1):81-82. (in Chinese)

Guo xiaolan. (2010). College Graduates Employment Issues and Strategies. Chinese Health Service Management, (01):50-59. (in Chinese)

$\mathrm{Hu}$ jinxiu, Wu baohua. (2010). Under the influence of the financial crisis, employment status of graduates in Hebei Province and countermeasures. Hebei Normal University (Educational Science Edition), (01):95-101. (in Chinese)

Jin yuqiu. (2009). After the financial crisis, foreign trade, employment and policy choices. Economic issues, (07):23-27. (in Chinese)

Table 1. The near future work plan of graduates in 2010

\begin{tabular}{|c|c|c|c|c|}
\hline Stay in the original work unit & Find a new job & Start a business & Study & Have no idea now \\
\hline $33.83 \%$ & $11.28 \%$ & $12.22 \%$ & $19.92 \%$ & 21.05 \\
\hline
\end{tabular}

Table 2 .

\begin{tabular}{|c|c|c|}
\hline \multirow[t]{2}{*}{ Internal capacity } & Strength & Weakness \\
\hline & $\begin{array}{l}\text { Use of Sichuan } \\
\text { Agricultural University } \\
\text { hundred prestigious } \\
\text { reputations to attract } \\
\text { employers. } \\
\text { professional inside } \\
\text { information, especially in } \\
\text { agriculture in economic } \\
\text { management } \\
\text { Common with the } \\
\text { hard-working, for fighting } \\
\text { spirit }\end{array}$ & $\begin{array}{l}\text { Students have a lack } \\
\text { of clear career goals } \\
\text { planning } \\
\text { conditions of practice } \\
\text { opportunities and practice } \\
\text { theoretical knowledge, but } \\
\text { not as good as other } \\
\text { professional sound } \\
\text { economic institutions } \\
\text { School location has } \\
\text { some negative effects } \\
\text { S Students lack } \\
\text { self-confidence }\end{array}$ \\
\hline \multirow[t]{2}{*}{ External factors } & Opportunities & Threats \\
\hline & $\begin{array}{l}\text { - State increasing } \\
\text { emphasis on "Agriculture," the } \\
\text { foundation of the constantly } \\
\text { increasing investments in } \\
\text { agriculture, for agricultural } \\
\text { institutions to provide students } \\
\text { show platform } \\
\text { Post-disaster } \\
\text { reconstruction in Sichuan, } \\
\text { arduous task of rural } \\
\text { reconstruction, urgent need to } \\
\text { agriculture and other related } \\
\text { professionals in economic } \\
\text { management } \\
\text { - The national } \\
\text { employment policy support, } \\
\text { such as the Western volunteers }\end{array}$ & $\begin{array}{l}\text { By the financial crisis, } \\
\text { employers do not want to } \\
\text { use the new graduates lack } \\
\text { work experience } \\
\text { pot outstanding } \\
\text { professional characteristics, } \\
\text { resulting in the form of } \\
\text { single job } \\
\text { Practical ability as } \\
\text { students in vocational } \\
\text { schools } \\
\text { Economically } \\
\text { backward western region, } \\
\text { the students do not want to } \\
\text { grass-roots-oriented } \\
\text { employment }\end{array}$ \\
\hline
\end{tabular}

